\title{
ALTERNATIVE ADDITIVES TO VASE SOLUTION THAT CAN PROLONG VASE LIFE OF CARNATION (Dianthus caryophyllus) FLOWERS.
}

Safia H.El-Hanafy.

Ornamental Horticulture Department, Faculty of Agriculture, Cairo University, Egypt.

\section{ABSTRACT}

Cut flowers have long been used for decoration and adornment. Studies are always going on to prescribe the most effective composition of vase solution that can preserve cut flowers at the best look, as long as possible.

In this experiment, carnation was chosen because of its known importance as a cut flower crop. Bacterial proliferation is known to be the main factor responsible for derangement of vase solution. Essential oils are famous for their antimicrobial activity which can be beneficial in improving the characteristics of vase solution. The aim of the experiment was to study the different effects resulting from the addition of essential oils to the holding solution of cut carnation (Dianthus caryophyllus) flowers, and its repercussions on the keeping quality and chemical composition of flowers, as well as on environmental safety and financial aspects.

Distilled water, 5\% glucose, and 5\% glucose $+200 \mathrm{ppm}$ 8- hydroxyquinoline (8-HQ) were used as control holding solutions, to be compared to six other holding solutions, each containing one different essential oil at a concentration of $200 \mathrm{ppm}+5 \%$ glucose. The oils used were extracted from cumin, thyme, parsley, peppermint, Seville orange and Melissa. The flowers were left in holding solution till the end of vase life.

The collected results included the duration of vase life, solution uptake, flower diameter, change in fresh flower weight, dry flower weight, anthocyanin and carbohydrate content, and microbiological examination of the holding solution.

Conclusively, it was found that, essential oils, particularly peppermint, cumin, Seville orange and Melissa oils, can represent adequate cheap and safe alternative additives to synthetic chemicals in vase solution that may prolong vase life of carnation flowers. This might be applicable to other cut flowers through the use of the same or other essential oils.

Key words: Carnation, essential oils, 8-HQ (8-hydroxyquinoline).

\section{INTRODUCTION}

The use of cut flowers has always remained an integral part of the social daily activities. Problems associated with the post-harvest control of flowers have engaged the attention of horticulturalists for very many years. Carnation is a 
dependable resource for income, as it is one of the world's most popular cut flower crops in commercial nurseries.

A common reason for premature in-vase welting is plugging of the process of water conduction in the stem xylem. Bacteria, yeast and/or fungi living in water or on the surface of the stem or foliage proliferate in the flower-holding containers. These microorganisms and their chemical products plug the stem ends, thus restricting water absorption.

Many chemicals such as citric acid, silver nitrate, silver thiosulfate, clorox, and the most effective, 8-hydroxy quinoline (8-HQ), were used to prevent microbial proliferation. However, 8-HQ is the most expensive and the most harmful preservative for human being, as it is very irritant to the eyes and respiratory airways.

Thyme, cumin, mint, and many spices demonstrate antimicrobial activity (Farag et al, 1989). The compounds responsible for antimicrobial activity of herbs are primarily phenolic components of their essential oil fractions (Beuchat, 1994).

Essential oils have been traditionally used since ancient times for preservation of food products (De et al, 1998). They have antimicrobial, bactericidal, ant oxidative, antiseptic and antitoxic activities (Julia, 1992). In this concern, essential oils offer natural photochemical that is safer and cheaper when compared to synthetic chemical preservatives. It was therefore logic to try using essential oils as additives to the glucose-containing vase solution. In this study, 6 different essential oils (each dissolved in the fat solvent Tween 40) were used, each being an alternative additive to vase solution, in place of 8-HQ or other chemicals.

Cumin, thyme, parsley, peppermint, Seville orange and Melissa oils were added to vase solution containing 5\% glucose syrup, with the aim of studying their effect on the longevity and keeping quality of vase flowers. The safety data of all the selected oils include being non-irritant, non-sensitizing and non-toxic compounds (Julia, 1992). The expected effects on vase flowers were all compared to those of 8-HQ, which is a well-known additive to flower-holding solutions.

\section{MATERIALS AND METHODS}

This study was carried out at the Ornamental Horticulture Department, Faculty of Agriculture, Cairo University, during two successive seasons of Nov. 2004 and Nov. 2005.

Carnation (Dianthus caryophyllus cv. Americana) flowers were obtained from a Commercial Farm in the brush stage in the early morning. The flowers were precooled to alleviate the effect of high field temperature, and wrapped in kraft paper in groups, each involving 20 flowers. The flowers were transported under dry conditions to the laboratory within one hour, and positioned in the holding solution after being sure that every flower had a stem length of $60 \mathrm{~cm}$ and 3 pairs of leaves in both seasons. The average flower weight was $16.68 \mathrm{~g}$. in the first season and $21.1 \mathrm{~g}$. in the second season. Every flower was put in a separate graded container having $100 \mathrm{ml}$ of holding solution.

The flowers were divided into nine groups, each being formed of 15 flowers. The first group was held in distilled water $\left(1^{\text {st }}\right.$ control), the second in $5 \%$ glucose syrup ( $2^{\text {nd }}$ control), the $3^{\text {rd }}$ group in $5 \%$ glucose syrup $+200 \mathrm{ppm}$ of $8-\mathrm{HQ}\left(3^{\text {rd }}\right.$ 
control), while the other 6 groups were treated with essential oils. Each of them was put in $5 \%$ glucose syrup $+200 \mathrm{ppm}$ of an essential oil. Thus, each treatment involved a different essential oil that had been freshly prepared in the laboratory by steam distillation prior to purchasing of flowers.

Cumin oil from Cuminum cyminum, family Apiaceae (Umbelliferae), was extracted by steam distillation of crushed ripe fruits. It is formed mainly of cumin aldehyde monoterpine hydrocarbons such as pinenes, terpinenes and cymene. Thyme oil from Thymus vulgaris, family Lamiaceae (Labiatae), was extracted by steam distillation of leaves. It is formed mainly of thymol and carvacrol. Parsley oil from Petroselinum sativum, fam. Apiaceae (Umbelliferae), was extracted by steam distillation of leaves. It is formed mainly of myristicin. Peppermint oil from Mentha piperita, fam. Lamiaceae (Labiatae), was extracted by steam distillation of flowering herb. It is formed mainly of menthol and menthone. Seville orange oil from Citrus aurantium, fam. Rutaceae, was extracted by steam distillation of flowers. It is formed mainly of limonene and myrcene. Melissa (lemon balm) oil from Melissa officinalis, fam. Lamiaceae (Labiatae), was extracted by steam distillation of leaves and flowering tops. It is formed mainly of citral and citronellol (Julia, 1992).

Each of the above-mentioned 6 oils was dissolved in the fat solvent Tween 40, before being added to $5 \%$ glucose syrup to give a concentration of $200 \mathrm{ppm}$. All experimental containers were kept under Laboratory conditions of $20 \pm 2^{\circ} \mathrm{C}$, around $65 \%$ relative humidity, and 1500 lux of continuous light.

The following data were recorded:

(1) The vase life of flowers (days), when the flowers of carnation started to show wilting of the petals and decrease of fresh weight.

(2) Total solution uptake per flower ( $\mathrm{ml})$.

(3) The rate of daily solution absorption $(\mathrm{ml})$ per flower, from the beginning of the experiment to the beginning of senescence.

(4) Flower diameter $(\mathrm{cm})$ one week after placing in solution.

(5) Percent change in fresh flower weight on the day of starting wilting.

(6) Terminal flower dry weight (g.).

(7) Anthocyanin content in fresh petals at the beginning of wilting (g. /100g.) according to Fuleki and Francis (1968).

(8) Total carbohydrate percentage in dry petals (according to Dubois et al, 1956).

(9) Microbiological examination of the holding solution, where $10 \mathrm{ml}$ sample of each solution was taken at the beginning of the experiment, and then repeated after 3 and 6 days. Each sample was serially diluted, by adding water peptone solution, cultured on standard agar plates and incubated at $30^{\circ} \mathrm{C}$ for $48 \mathrm{~h}$. The total viable bacterial colonies were then counted in glucose-yeast extract agar (Postage, 1969).

The design for this experiment was complete randomized design (CRD) with three replicates for each treatment. Data were analyzed with the Analysis of Variance (ANOVA) according to Snedecor and Cochran (1980) using Mstatc program. When significant differences $(\mathrm{P}<0.05)$ were detected, the least significant difference (LSD) test was used to separate the mean values according to Steel and Torrie (1981). 


\section{RESULTS AND DISCUSSION}

\section{1-Vase life:}

Flower life means the time to decline in fresh weight (Michael, 2000). The effect of vase solution on longevity of carnation (Dianthus caryophyllus) flowers is demonstrated in Table (1). All treatments of essential oils (200 ppm) and 8-HQ (200 ppm) significantly prolonged vase life in comparison to either distilled water or 5\% glucose solution alone. The highest mean values for vase life were recorded with peppermint oil in both seasons, being 17.31 and 13.43 days in the first and second seasons respectively.

Table 1. Effect of essential oils on vase life (days), total solution uptake (ml) and daily uptake $(\mathrm{ml})$ in the $1^{\text {st }}$ and $2^{\text {nd }}$ seasons in carnation flowers

\begin{tabular}{clcccccc}
\hline \multirow{2}{*}{ No. } & \multirow{2}{*}{ Treatments } & \multicolumn{2}{c}{ Vase life } & \multicolumn{2}{c}{$\begin{array}{c}\text { Total solution } \\
\text { uptake }\end{array}$} & \multicolumn{2}{c}{$\begin{array}{c}\text { Daily uptake } \\
\text { ADSU }\end{array}$} \\
\cline { 3 - 8 } & & $1^{\text {st }}$ & $2^{\text {nd }}$ & $1^{\text {st }}$ & $2^{\text {nd }}$ & $1^{\text {st }}$ & $2^{\text {nd }}$ \\
\hline C1 & Distilled water & $10.59 \mathrm{~d}$ & $9.13 \mathrm{e}$ & $15.75 \mathrm{e}$ & $13.78 \mathrm{e}$ & $1.49 \mathrm{a}$ & $1.51 \mathrm{a}$ \\
C2 & $\mathbf{5 \%}$ glucose & $10.03 \mathrm{~d}$ & $8.72 \mathrm{e}$ & $13.42 \mathrm{~g}$ & $11.25 \mathrm{f}$ & $1.34 \mathrm{~b}$ & $1.29 \mathrm{~b}$ \\
C3 & +8-HQ & $14.60 \mathrm{~b}$ & $13.71 \mathrm{a}$ & $17.80 \mathrm{c}$ & $16.06 \mathrm{ab}$ & $1.22 \mathrm{~cd}$ & $1.17 \mathrm{~d}$ \\
T1 & +Cumin oil & $14.26 \mathrm{bc}$ & $12.33 \mathrm{bc}$ & $18.25 \mathrm{~b}$ & $15.01 \mathrm{~cd}$ & $1.29 \mathrm{bc}$ & $1.22 \mathrm{bcd}$ \\
T2 & +Thyme oil & $14.83 \mathrm{~b}$ & $12.86 \mathrm{~b}$ & $18.60 \mathrm{~b}$ & $16.01 \mathrm{~b}$ & $1.25 \mathrm{bcd}$ & $1.25 \mathrm{bc}$ \\
T3 & +Parsley oil & $13.20 \mathrm{c}$ & $11.58 \mathrm{~d}$ & $15.33 \mathrm{f}$ & $14.01 \mathrm{e}$ & $1.16 \mathrm{de}$ & $1.21 \mathrm{bcd}$ \\
T4 & +Peppermint oil & $17.25 \mathrm{a}$ & $13.83 \mathrm{a}$ & $19.90 \mathrm{a}$ & $16.51 \mathrm{a}$ & $1.15 \mathrm{de}$ & $1.19 \mathrm{~cd}$ \\
T5 & +Seville orange oil & $14.94 \mathrm{~b}$ & $12.03 \mathrm{~cd}$ & $17.67 \mathrm{c}$ & $14.71 \mathrm{~d}$ & $1.18 \mathrm{cde}$ & $1.22 \mathrm{bcd}$ \\
T6 & +Melissa oil & $14.73 \mathrm{~b}$ & $12.63 \mathrm{~b}$ & $16.33 \mathrm{~d}$ & $15.43 \mathrm{c}$ & $1.11 \mathrm{e}$ & $1.22 \mathrm{bcd}$ \\
\hline L.S.D. at 5\% & $\mathbf{1 . 2 0}$ & $\mathbf{0 . 5 8}$ & $\mathbf{0 . 4 1}$ & $\mathbf{0 . 4 6}$ & $\mathbf{0 . 1 1}$ & $\mathbf{0 . 0 8}$ \\
\hline T1-T6 & & 14.87 & $12.54 \mathrm{~b}$ & 17.68 & $15.28 \mathrm{~b}$ & 1.19 & 1.22 \\
C3 & & 14.6 & $13.71 \mathrm{a}$ & 17.80 & $16.06 \mathrm{a}$ & 1.22 & 1.17 \\
T1-T6 compared to C3 & N.S. & S. & N.S. & S. & N.S & N.S.
\end{tabular}

The means with different letters within each column are significant $(\mathrm{P}<0.05)$, while the means without letters are insignificant.

$\mathrm{C}=$ Control $\quad \mathrm{T}=$ Treatment $\mathrm{S}=$ Significant N.S. = Non-significant $\quad 8-\mathrm{HQ}=8$ hydroxyquinoline. ADSU =Average daily solution uptake.

There were no significant differences in vase life duration between essential oils and 8-HQ treatments in both seasons. The mean values were 14.30 and 12.39 days with essential oils, and 15.13 and 13.13 days with 8 -HQ in the $1^{\text {st }}$ and $2^{\text {nd }}$ seasons respectively. In different studies on cut flowers, sucrose +8-HQ extended the vase life.

This was confirmed by Vinga et al (1999) on Genista monosperma. Kushal et al (2003) on carnation cv. Nelon, found that different concentrations of 8-HQC increased the vase life of carnation (12.46 days). When Huang et al (2006) treated cut rose flowers with 8-HQS + sucrose, their longevity was 6 days. 


\section{2-Total solution uptake:}

The effects of essential oil and 8-HQ treatments on solution uptake are shown in Table 1 . Solution uptake significantly increased with $8-\mathrm{HQ}$, and with most of the essential oils in the two seasons, in comparison to distilled water or glucose. In comparing total solution uptake by flowers in the presence of essential oils, and that in the presence of 8-HQ, different results were obtained.

In the first season, peppermint, thyme and cumin oils showed significantly higher values, while Seville orange oil showed an insignificantly lower mean value. Only parsley and Melissa oils gave significantly lower mean values (15.33 and 16.33 compared to $17.80 \mathrm{ml}$. respectively). In the second season, peppermint oil gave an insignificantly higher value, while thyme oil showed an insignificantly lower value. The other 4 oils had significantly lower values in comparison to 8-HQ $(14,14.71,15,15.43$ compared to $16.06 \mathrm{ml}$.).

In general, essential oils in the first season had an insignificantly lower value, while in the second season they had a significantly lower value than that of 8-HQ. However, this irregularly noted little decrease of total solution uptake with some essential oils in comparison to 8-HQ was not associated with affection of longevity, that showed no significant differences in comparison to 8-HQ in both seasons. A finding in different studies that, extending the vase life is always associated with increased water uptake (Shenggen et al, 2006). However, senescence is a change located mainly in the petal cells, and is not directly related to the overall water relations (Theophanes and Kenneth. 1997).

The use of essential oils must be having one or more other mechanisms (beside maintaining adequate water uptake) enhancing vase life longevity, like having a possible direct or indirect effect on the formation of senescence proteins within the petal cells; the accumulation of such proteins in petals has an important impact on wilting (Wouter et al, 1995).

Another possibility is the presence of a temperature-lowering effect of volatile oils on petals (during conduction of the experiment, increased intensity of flower odour was always noted with volatile oil treatments, particularly in case of cumin and peppermint oils. Higher temperatures are known to be detrimental to flowers, as it is known to increase both respiration and ethylene production, both of which are harmful to petals (Irving and Honnor, 1994) The specific chemical nature of essential oils might conceal an explanation for any of these possibilities.

\section{3-Average daily solution uptake (ADSU):}

The use of any of the essential oils was associated with decreased ADSU in comparison to distilled water or 5\% glucose solution in both seasons, with the decrease being significant with Melissa, peppermint, parsley and Seville orange oils in the first season, and with only peppermint oil in the second season. With 8$\mathrm{HQ}$, the ADSU was significantly lower than that with distilled water or $5 \%$ glucose in both seasons. In the first season, only Melissa oil had a significantly lower ADSU value than 8-HQ, while only thyme oil had a significantly higher value in the second season.

There was no significant difference between the general ADSU with essential oils and that with 8-HQ in both seasons. On the contrary, Shanan (2003) on carnation and Kim and Lee (2001), on rose cut flowers found that daily 
absorption of vase solution was higher for a longer duration with sucrose and 8-HQ compared to water.

\section{4-Flower diameter:}

Concerning the effect of essential oils in vase solution on the diameter of flowers, it seems from Table (2) that all treatments with essential oils and also treatment with 8-HQ significantly increased flower diameter compared to distilled water and glucose solution. As regards the comparison of effect of essential oils and that of 8-HQ, there was no significant difference in the first season, while in the second season 8-HQ gave significantly bigger diameter than, parsley, Seville orange, Melissa and peppermint oils (7.55, 7.30, 7.25, 7.22 and 7.09 respectively). Cumin and thyme had almost the same effect as 8-HQ in the second season.

Concerning the general effect of essential oils, the mean value of flower diameter with essential oils was exactly the same as that with 8-HQ in the first season $(7.36 \mathrm{~cm})$, while it was lower in the second season compared to 8-HQ (7.28 versus 7.55). It seems in general that essential oils are as efficient as 8-HQ as a vase solution preservative in keeping the nutrient status of cut flowers. Shanan (2003) found that vase solution containing 5\% sucrose + $150 \mathrm{ppm} 8$-HQ increased the diameter of carnation flowers. Also Ichimura et al (1999) on rose flowers, found similar results.

\section{5-Percentage reduction in fresh weight of cut flowers:}

The results are demonstrated in Table 2. In both seasons, essential oils and 8HQ generally limited percentage reduction in fresh weight of carnation in comparison to distilled water and $5 \%$ glucose. In the $1^{\text {st }}$ season, both peppermint and cumin oils gave almost the same extent of reduction as 8-HQ (5.52, 6.65 and $6.36 \%$ respectively), while the other 4 oils were associated with more remarkable reduction. There was no significant difference between the general effect of essential oils and that of 8-HQ in both seasons. These results show that addition of essential oils to vase solution gives almost similar results to 8-HQ in minimizing fresh weight reduction till the time of wilting, a finding which demonstrates that essential oils are as efficient as 8-HQ in securing the nutrient status of cut flowers. Ichimura et al (1999) on adding sucrose + H-QS, and Lee and Kim (2001) on adding $3 \%$ sucrose $+200 \mathrm{ppm} \mathrm{H}-\mathrm{QS}+0.1 \mathrm{mg}$ methionine to the vase solution of cut rose flowers had similar results.

\section{6- Dry weight of flowers (g):}

Data are presented in Table (2). The addition of essential oils or 8-HQ was generally associated with higher dry weights than those associated with distilled water or 5\% glucose in both seasons. On the other hand, the first season demonstrated almost similar or slightly higher results of Seville orange, thyme, Melissa, cumin and peppermint oils in comparison to 8-HQ (2.69, 2.88, 2.90, 2.93 and 2.98 in comparison to $2.88 \mathrm{~g}$. respectively), with peppermint oil being the most effective. Only parsley showed a significantly lower result than 8-HQ (2.63 compared to 2.88 g. respectively). In the second season, almost similar or slightly different results were obtained with peppermint, cumin, parsley and thyme oils in comparison to 8-HQ $(3.33,3.45,3.51$ and 3.71 in comparison to $3.52 \mathrm{~g}$. respectively), while significantly lower results were obtained with Melissa and Seville orange oils (2.97 and $3.13 \mathrm{~g}$. respectively). 
Table 2. Effect of essential oils on flower, diameter $(\mathrm{cm})$, percentage Reduction in fresh and dry weight (g.) in the $1^{\text {st }}$ and $2^{\text {nd }}$ seasons in carnation flowers

\begin{tabular}{|c|c|c|c|c|c|c|c|}
\hline \multirow[t]{2}{*}{ No. } & \multirow[t]{2}{*}{ Treatments } & \multirow{2}{*}{\multicolumn{2}{|c|}{$\begin{array}{c}\text { Flower diameter } \\
\mathbf{1}^{\text {st }} \\
2^{\text {nd }}\end{array}$}} & \multicolumn{4}{|c|}{$\begin{array}{l}\text { Reduction. } \\
(\%)\end{array}$} \\
\hline & & & & \multicolumn{2}{|c|}{ Fresh weight (g.) } & \multicolumn{2}{|c|}{ Dry weight (g.) } \\
\hline C1 & Distilled water & $6.31 \mathrm{~d}$ & $5.44 \mathrm{f}$ & $13.29 \mathrm{a}$ & $14.09 \mathrm{~b}$ & $2.58 \mathrm{c}$ & $2.04 \mathrm{f}$ \\
\hline $\mathrm{C} 2$ & $5 \%$ Glucose & $6.72 \mathrm{c}$ & $6.74 \mathrm{e}$ & $12.88 \mathrm{a}$ & $15.93 \mathrm{a}$ & $2.51 \mathrm{c}$ & $2.65 \mathrm{e}$ \\
\hline C3 & +8 -HQ & $7.36 \mathrm{ab}$ & $7.55 \mathrm{a}$ & $6.36 \mathrm{c}$ & $11.07 \mathrm{~d}$ & $2.88 \mathrm{ab}$ & $3.52 \mathrm{ab}$ \\
\hline T1 & + Cumin oil & $7.46 \mathrm{a}$ & $7.45 \mathrm{ab}$ & $6.65 \mathrm{c}$ & $11.08 \mathrm{~d}$ & 2.93ab & $3.45 a b c$ \\
\hline T2 & +Thyme oil & $7.34 \mathrm{ab}$ & 7.37abc & $9.99 \mathrm{~b}$ & 9.19ef & $2.88 \mathrm{ab}$ & $3.71 \mathrm{a}$ \\
\hline T3 & +Parsley oil & $7.36 \mathrm{ab}$ & $7.30 \mathrm{bcd}$ & $12.12 \mathrm{a}$ & $12.73 \mathrm{c}$ & $2.63 \mathrm{c}$ & $3.51 \mathrm{ab}$ \\
\hline T4 & +Peppermint oil & $7.50 \mathrm{a}$ & $7.09 \mathrm{~d}$ & $5.52 \mathrm{c}$ & 9.12ef & $2.98 \mathrm{a}$ & $3.33 \mathrm{bcd}$ \\
\hline T5 & +Seville orange oil & $7.47 \mathrm{a}$ & $7.25 \mathrm{bcd}$ & $9.52 \mathrm{~b}$ & $9.85 \mathrm{de}$ & $2.69 \mathrm{bc}$ & $3.13 \mathrm{~cd}$ \\
\hline T6 & +Melissa oil & $7.06 \mathrm{~b}$ & $7.22 \mathrm{~cd}$ & $9.54 \mathrm{~b}$ & $8.24 \mathrm{f}$ & 2.90ab & $2.97 \mathrm{de}$ \\
\hline \multicolumn{2}{|c|}{ L.S.D .at 5\% } & 0.33 & 0.23 & 1.97 & 1.24 & 0.24 & 0.38 \\
\hline \multicolumn{2}{|c|}{ T1-T6 } & 7.36 & $7.28 \mathrm{~b}$ & 8.89 & 10.03 & 2.83 & 3.35 \\
\hline \multicolumn{2}{|l|}{ C3 } & 7.36 & $7.55 \mathrm{a}$ & 6.36 & 11.07 & 2.88 & 3.52 \\
\hline \multicolumn{2}{|c|}{ T1-T6 compared to C3 } & N.S. & S. & N.S. & N.S. & N.S & N.S. \\
\hline
\end{tabular}

The means with different letters within each column are significant $(\mathrm{P}<0.05)$, while the means without letters are insignificant.

$\mathrm{C}=$ Control. $\quad \mathrm{T}=$ Treatment. $\quad \mathrm{S} .=$ Significant. $\quad$ N.S. $=$ Non-significant. $\quad 8-\mathrm{HQ}=$ 8-hydroxyquinoline.

There was no significant difference between the general results associated with essential oils and those with 8-HQ in both seasons, thus indicating that the use of essential oils can be an adequate alternative to 8-HQ in maintaining the solid content of cut flowers.

\section{7-Anthocyanin (g. /100g.)}

The results are demonstrated in Table 3. All essential oils increased significantly the anthocyanin content in fresh petals of carnation flowers in both seasons in comparison to distilled water or $5 \%$ glucose, except for thyme in the second season, where the increase was insignificant. On the other hand, 8-HQ was associated with a significant increase in comparison to distilled water and an insignificant increase in comparison to $5 \%$ glucose in both seasons.

Concerning the effect of essential oils in comparison to 8-HQ, Seville orange, peppermint, parsley, thyme, cumin and Melissa oils gave significantly higher increases in the first season $(0.67,0.71,0.71,0.87,0.92$ and 0.99 compare to $0.61 \mathrm{~g}$. $/ 100 \mathrm{~g}$. of fresh petals respectively). In the second season, cumin, Seville orange and parsley gave significantly higher results $(0.92,0.97$ and 0.99 g. $/ 100 \mathrm{~g}$. respectively), while thyme and Melissa gave insignificant increments $(0.70$ and $0.76 \mathrm{~g} . / 100 \mathrm{~g}$. respectively), and peppermint gave the same increase in comparison 
Table 3. Effect of essential oils on anthocyanin percentage in fresh petals and percentage of total carbohydrates in dry petals in the $1^{\text {st }}$ and $2^{\text {nd }}$ seasons in carnation.

\begin{tabular}{|c|c|c|c|c|c|}
\hline \multirow{2}{*}{ No. } & \multirow[t]{2}{*}{ Treatments } & \multicolumn{2}{|c|}{ Anthocyanin(\%) } & \multicolumn{2}{|c|}{ Total carbohydrates (\%) } \\
\hline & & $1^{\text {st }}$ season & $\begin{array}{c}2^{\text {nd }} \\
\text { season }\end{array}$ & $\begin{array}{c}1^{\text {st }} \\
\text { season }\end{array}$ & $\begin{array}{c}2^{\text {nd }} \\
\text { season }\end{array}$ \\
\hline C1 & Distilled water & $0.54 \mathrm{e}$ & $0.56 \mathrm{e}$ & $33.85 \mathrm{~d}$ & $39.56 \mathrm{~g}$ \\
\hline C2 & $5 \%$ Glucose & $0.60 \mathrm{~d}$ & $0.67 \mathrm{~d}$ & $36.44 \mathrm{~cd}$ & $40.66 \mathrm{f}$ \\
\hline $\mathrm{C} 3$ & $+8-\mathrm{HQ}$ & $0.61 \mathrm{~d}$ & $0.71 \mathrm{~cd}$ & $44.31 \mathrm{a}$ & $45.59 \mathrm{~b}$ \\
\hline T1 & +Cumin oil & $0.92 b$ & $0.92 b$ & $39.57 \mathrm{bc}$ & $47.27 \mathrm{a}$ \\
\hline $\mathbf{T} 2$ & +Thyme oil & $0.87 \mathrm{~b}$ & $0.70 \mathrm{~d}$ & $38.77 \mathrm{bc}$ & $44.54 \mathrm{c}$ \\
\hline T3 & +Parsley oil & $0.71 \mathrm{c}$ & $0.99 \mathrm{a}$ & $45.03 \mathrm{a}$ & $45.40 \mathrm{~b}$ \\
\hline T4 & +Peppermint oil & $0.71 \mathrm{c}$ & $0.71 \mathrm{~cd}$ & $40.39 \mathrm{~b}$ & $38.28 \mathrm{~h}$ \\
\hline T5 & +Seville orange oil & $0.67 \mathrm{c}$ & $0.97 \mathrm{ab}$ & $43.76 \mathrm{a}$ & $43.50 \mathrm{~d}$ \\
\hline T6 & +Melissa oil & $0.99 \mathrm{a}$ & $0.76 \mathrm{c}$ & $44.13 \mathrm{a}$ & $42.11 \mathrm{e}$ \\
\hline L.S.D.at 5\% & & 0.05 & 0.05 & 3.30 & 0.69 \\
\hline T1-T6 & & $0.81 \mathrm{a}$ & 0.84 & $41.94 \mathrm{~b}$ & 43.52 \\
\hline C3 & & $0.61 \mathrm{~b}$ & 0.71 & $44.31 \mathrm{a}$ & 45.59 \\
\hline T1-T6 compar & to $\mathrm{C3}$ & S. & N.S. & S. & N.S. \\
\hline
\end{tabular}

The means with different letters within each column are significant $(\mathrm{P}<0.05)$, while the means without letters are insignificant.

$\mathrm{C}=$ Control $\mathrm{T}=$ Treatment $\quad \mathrm{S} .=$ Significant $\quad$ N.S. $=$ Non-significant $\quad 8-\mathrm{HQ}=8$ hydroxyquinoline..

to 8-HQ (0.71 g. /100g.). The mean value of increments induced by essential oils was more than that of 8-HQ in both seasons, with the difference being significant in the first season (0.81 compared to $0.61 \mathrm{~g}$. $/ 100 \mathrm{~g}$.), and insignificant in the second season ( 0.84 compared to $0.71 \mathrm{~g}$. $/ 100 \mathrm{~g}$.)

Thus, unlike 5\% glucose alone, or even with 8-HQ, the addition of essential oils to vase solution is associated with a remarkable increase of anthocyanin content of fresh petals, which is a known source of improved look of cut flowers. Shanan (2003), found that addition of $150 \mathrm{ppm} \mathrm{8-HQ} \mathrm{and} \mathrm{5 \%} \mathrm{sucrose} \mathrm{to} \mathrm{vase}$ solution of carnation flowers decreased the anthocyanin content of fresh petals compared to distilled water.

\section{8-Total carbohydrates in dry petals (\%):}

The results are presented in Table 3. In the first season, a significant increase was noted with peppermint, Seville orange, Melissa and parsley in comparison to distilled water or $5 \%$ glucose, while thyme and cumin had a significant increase in comparison to water, and an insignificant increase in comparison to $5 \%$ glucose. In the second season, all oils gave significantly higher carbohydrates in comparison to distilled water or $5 \%$ glucose. Regarding the effect of 8-HQ, it was associated with significantly higher total carbohydrate percentage in both seasons in comparison to 
distilled water or $5 \%$ glucose. In comparing essential oils with 8-HQ in the first season, no significant difference was found with Seville orange, Melissa and parsley, while a significant decrease was noted with thyme, cumin and peppermint. In the second season, cumin oil was associated with a significantly higher total carbohydrate percentage, while parsley was as effective as 8-HQ. The mean carbohydrate percentage with essential oils in general was less than 8-HQ in both seasons (41.94 compared to $44.31 \%$ in the $1^{\text {st }}$ season, and 43.52 compared to $45.59 \%$ in the $2^{\text {nd }}$ season). Ichimura et al. (1999) on Rosa hybrida cv. Sonia and Shanan (2003) on carnation reported that using vase solution containing 5\% sucrose mixed with 8-HQ increased soluble sugar content in flowers. Also, Huang et al. (2006), on cut rose flowers found that the concentrations of various sugars in petals were highest with sucrose +8 -HQS treatment.

\section{9-The $\mathrm{pH}$ values in vase solution:}

The results are shown in Table 4 . The $\mathrm{pH}$ at the end of vase life significantly decreased with 8-HQ and with most of the essential oils in the 2 seasons, $n$ comparison to distilled water or glucose alone. In comparing $\mathrm{pH}$ in the presence of essential oils and that in the presence of 8-HQ at the end of vase life, all oils showed lower $\mathrm{pH}$ values in both seasons. A lower $\mathrm{pH}$ of vase solution is probably associated with lower $\mathrm{pH}$ of petal sap, which is said to be associated with a better viability of petals (Irving and Honnor, 1994). The remarkable acidity of vase solution in the presence of essential oils is attributed to their acidic constituents.

Table 4. Values of $\mathrm{pH}$ at the start and end of vase life in holding solution of carnation flowers in the $1^{\text {st }}$ and $2^{\text {nd }}$ seasons $(2004 / 2005)$

\begin{tabular}{|c|c|c|c|c|c|}
\hline \multirow[t]{2}{*}{ No. } & \multirow[t]{2}{*}{ Treatments } & \multicolumn{2}{|c|}{ First season } & \multicolumn{2}{|c|}{ Second season } \\
\hline & & Start & End & Start & End \\
\hline C1 & Distilled water & 7.06 & $5.74 \mathrm{a}$ & 7.11 & $5.81 \mathrm{a}$ \\
\hline C2 & 5\% Glucose & 6.95 & $5.50 \mathrm{a}$ & 6.50 & $4.97 \mathrm{~b}$ \\
\hline $\mathbf{C 3}$ & $+8-\mathrm{HQ}$ & 6.24 & $4.60 \mathrm{~b}$ & 7.07 & $4.37 \mathrm{c}$ \\
\hline T1 & +Cumin oil & 7.54 & $3.39 \mathrm{~d}$ & 6.96 & $4.23 \mathrm{c}$ \\
\hline $\mathbf{T 2}$ & +Thyme oil & 6.84 & $3.75 \mathrm{~cd}$ & 6.95 & $4.19 \mathrm{~cd}$ \\
\hline $\mathbf{T 3}$ & +Parsley oil & 6.71 & $4.14 \mathrm{bc}$ & 7.07 & $4.06 \mathrm{~cd}$ \\
\hline T4 & +Peppermint oil & 6.82 & $3.82 \mathrm{~cd}$ & 7.12 & $3.98 \mathrm{~cd}$ \\
\hline T5 & +Seville orange oil & 6.77 & $4.00 \mathrm{c}$ & 7.10 & $3.64 \mathrm{~d}$ \\
\hline T6 & +Melissa oil & 6.04 & $4.25 \mathrm{bc}$ & 7.26 & $3.93 \mathrm{~cd}$ \\
\hline \multicolumn{2}{|c|}{ L.S.D. at 5\% } & & 0.548 & & 0.566 \\
\hline \multicolumn{2}{|c|}{ T1-T6 } & & $3.89 \mathrm{~b}$ & & $4.01 \mathrm{~b}$ \\
\hline \multicolumn{2}{|l|}{$\mathbf{C 3}$} & & $4.60 \mathrm{a}$ & & $4.37 \mathrm{a}$ \\
\hline \multicolumn{2}{|c|}{ T1-T6 compared to C3 } & & $\mathbf{S}$ & & $\mathbf{S}$ \\
\hline
\end{tabular}

The means with different letters within each column are significant $(\mathrm{P}<0.05)$, while the means without letters are insignificant.

$\mathrm{C}=$ Control $\quad \mathrm{T}=$ Treatment $\quad \mathrm{S} .=$ Significant $\quad$ N.S. $=$ Non-significant $\quad 8-\mathrm{HQ}=8$ hydroxyquinoline. 
Table 5 demonstrates how far the addition of 8-HQ or essential oils to $5 \%$ glucose has a preservative activity against bacterial proliferation in vase solution of carnation (Dianthus caryophyllus) flowers. 8-HQ and 4 of the essential oils (cumin, thyme, mint and Melissa) significantly limited the increase in bacterial count by the end of the $6^{\text {th }}$ day, in comparison to either distilled water or $5 \%$ glucose solution in both seasons.

Even the other 2 oils (parsley and Seville orange), when added to 5\% glucose, they limited bacterial proliferation to the degree associated with distilled water or even less, while the limitation they induced was highly significant in comparison to 5\% glucose solution alone in both seasons.

Regarding the general effect of essential oils in comparison to 8HQ, the mean bacterial count by the end of the $6^{\text {th }}$ day was higher with essential oils, with the increase ranging between being significant in the first season and insignificant in the second. The longevity and look characteristics of carnation were however unaffected by these differences as seen in the above-mentioned results. Bacterial enzymes and by-products are the direct detrimental agents harming longevity (Henriette and Frank, 1989). Essential oils might have a protective effect against such substances which may further minimize the deranging effect of bacteria.

Table (5): Count of bacterial colonies per ml. of vase solution of carnation flowers in 2004 and 2005 seasons, at the start of experiment, after 3days and after 6 days

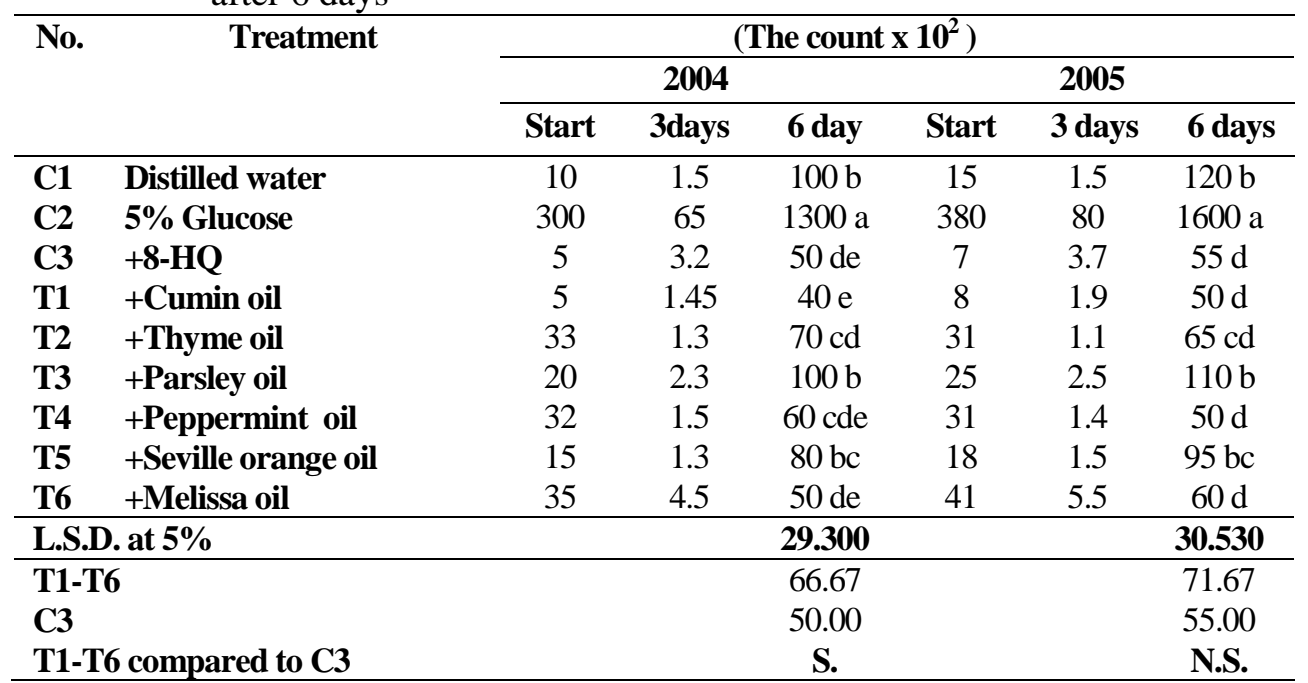

The means with different letters within each column are significant $(\mathrm{P}<0.05)$, while the means without letters are insignificant.

$\mathrm{C}=$ Control $\mathrm{T}=$ Treatment $\quad$ Dist. $=$ Distilled $\quad \mathrm{G} .=$ Glucose $\mathrm{S} .=$ Significant $\quad$ N.S. $=$ Non-significant $8 \mathrm{HQ}=8$-hydroxyquinoline

Kushal et al. (2003) on carnation cut flowers recorded antimicrobial activity for 8-HQ, with associated vase life longevity. Didry et al. (1994) found that the oil content in thyme shows a prominent antibacterial activity. Also, Pattnaik et al (1997) on mint, detected similar antibacterial effects. Helmy (2006) found that melissa oil exhibited antimicrobial activities. Cumin oil was also effective in 
limiting bacterial proliferation during the storage of flavored pan bread (Abdelazem, 2007). The compounds responsible for antimicrobial activity of herbal oils are primarily phenolic components of the essential oil fraction (Beuchat, 1994).

From the overall previous results, it can thus be found that, in spite of the mild superiority of 8-HQ in limitation of bacterial proliferation, the preservative activity of essential oils was quite enough to allow adequate elongation of the vase life, with no significant differences in comparison to 8-HQ. There was also no significant difference in the average daily solution uptake. In addition, essential oils were as efficient as 8-HQ in keeping the nutrient status and general look of cut flowers, being indicated by almost equally limiting the reduction in fresh weight, and maintaining the solid content of flowers, besides securing a higher content of anthocyanin pigment in fresh petals in comparison to 8-HQ.

This gain associated with the use of essential oils, might be attributed to the significantly higher acidity of their vase solution which is known to facilitate access of nutrient solution via the vascular bundles, in addition to its accept Table level of antimicrobial activity. Other unknown mechanisms might be underlying this gain.

Conclusively, it can thus be concluded that essential oils, particularly peppermint, cumin, Seville orange and Melissa oils can represent adequate cheap and safe alternative additives to synthetic chemicals in vase solution that may prolong vase life of carnation flowers. This might be applicable to other cut flowers through the use of the same or other essential oils.

\section{REFERENCES}

Abdelazim, A.S. (2007): Technochemical and biological studies on some spices and their volatile oils used in bakery products. M.Sc.Thesis. Agric. Sci., Food Science and Technology Dep., Faculty of Agriculture, Cairo University.

Beuchat, L.R. (1994): Antimicrobial properties of spices and their essential oils. In: Natural Antimicrobial Systems and food preservation, Dillon V.M., and Board R.G. (eds). Wallingford. UK: CAB.Intl; P. 167-179.

De, L.C.; S.K. Bhattacharjee and R.L. Misra (1998): Post harvest life of pulsed gladiolus spikes affected by different chemicals. Journal of Ornamental Horticulture; 4(1): 18-22.

Didry, N.; L. Dubreuil and M. Pinkas (1994): Activity of thymol, carvacrol, cinnamaldehyde and eugenol on oral bacteria. Pharm. Acta Helv; 69:25-28.

Dubois, M.; F. Smith; K.A. Gilles; J.K. Hamilton, and P.A. Rebers, (1956). Colorimetric method for determination of sugars and related substances. Annal. Chem., 28(3):350-356.

Farag, R.S.; Z.Y. Daw; F.M. Hewedi and G.S.A. El-Baroty (1989): Antimicrobial activity of some Egyptian spice essential oils. J.food Prot.; 52:665. 
Fuleki, T. and F.J. Francis (1968): Quantitative methods for anthocyanin extraction and determination of total anthocyanin in cranberries. $J$ Food Scie.;33: 72-77.

Helmy, S.A. (2006): Antioxidative properties and antimicrobial activity of different aromatic extracts of Melissa officinalis L. Arab. Univ. J. Agric. Sci., Ain Shams Univ., Cairo; 14(1):299-316.

Henriette, M.C.P. and M.R. Frank (1989): The influence of purified microbial pectic enzymes on the xylem anatomy, water uptake and vase life of Rosa cultivar 'Sonia'. Scientia Horticulturae, Feb.; 38(12):147-60.

Huang, K.L.; J. Liao, R.S. Shen; W.S. Chen and Y.H. Lin (2006): The synergistic effect of maleic acid hydrazide (1,2-dihydro-3,6pyridazinedione) and sucrose on vase life of cut roses. Australian Journal of Experimental Agriculture; 42(5):637-41.

Ichimura, K.; K. Kojima and R. Goto (1999): Effects of temperature, 8-hydroxyquinoline sulphate and sucrose on the vase life of cut rose flowers. Postharvest Biology and Technology, Jan.; 15(1):33-40.

Irving, D.V. and L.Honnor (1994): Carnations: effects of high concentrations of carbon dioxide on flower physiology and longevity. Postharvest Biology and Technology, June;4(3):281-87.

Julia, L. (1992): The encyclopaedia of essential oils. $1^{\text {st }}$ ed. Element Books Limited Longmead Shaftes bury, Dorset.

Kim, Y. A. and J.S. Lee (2001): Vase life and water balance of cut rose cultivars as affected by preservative solutions containing sucrose, 8 hydroxyquinoline sulfate, ethionine, and aluminium sulfate. Journalof-the-korean-sosciety-for-horticultural-science.; 42(3):325-330.

Kushal, S.P.J.; P. Singh and R. Kumar (2003): Effect of biocides, CaNO3 and STS on keeping quality of carnation. Journal of ornamental horticulture new Series. ;6(2):143-144.

Lee, J.S. and Y.A. Kim (2001): Effects of harvesting stages and holding solutions on quality and vase life of cut "Madelon" rose flowers. Journal-of-the-korean-sosciety-for-horticultural-science.; $\quad$ 42(6):743747.

Michael, K. (2000): Selection of biocides for use in floral preservatives. Postharvest Biology and Technology, Apr., 18(3):227-234.

Pattnaik, S.; V.R. Subramanyam; M. Bapaji and C.R. Kole (1997): Antibacterial and antifungal activity of aromatic constituents of essential oils. Microbios.; 89:39-46.

Postage, J.R. (1969): Viable counts and viability. In: Methods in microbiology. Norris, J.R. , Robbens , D.W. (eds), Vol.1. Academic press, London, P.A. N.Y., 611-28.

Shanan, N.T.A. (2003): Postharvest studies on cut carnation flowers (Dianthus caryophyllus). M.Sc. thesis, Ornamental Horticulture Department, Faculty of Agriculture, Cairo University. 
Shenggen, He; Daryl C. Joyce; Donald E. Irving and John D. Faragher (2006): Stem end blockage in cut Grevillea "CrimsonYul-lo" inflorescences. Postharvest Biology and Technology.; 41(1):78-84.

Snedecor, G. W. and Cochran, W. G. (1980): Statistical Methods, 6th Ed. The Iowa State Univ. press, Amer. Iowa, USA, 593.

Steel, R. G. D. and J. H. Torrie (1981): Principles and Procedures of Statistics: A Biometrical Approach. $2^{\text {nd }}$ Ed. McGraw-Hill Book Co., New York, NY.

Theophanes, S. and C. G. Kenneth (1997): Effects of hypoxia on respiration and the onset of senescence in cut carnation flowers (Dianthus caryophyllus L.). Postharvest Biology and Technology, Feb.; 10(2): 145-53.

Vinga, R.; M. Devecchi and E. Accati (1999): Keeping quality of flowering stems of broom. Colture Protette; 28(2):103-106.

Wouter, G. van Doorn; H. Harmannus and J.S. Song (1995): Water relations and senescence of cut Iris flowers: effects of cycloheximide. Postharvest Biology and Technology, Apr.; 5(4):345-51.

\section{بائل تضاف لمحلول الزهرية بهدف إطالة حياة زهور القرنفل المقطوفة}

$$
\text { قفية حمدى محمود الحنفى }
$$

تستخدم الأزهار المقطوفة منذ زمن بعيد فى التزبين، ولرائحتها الزكية. وتمضى الدر اسات بشكل مستمر لوصف أفضل تركيب لمحلول الزهنية هرية يستطيع ان يحتفظ بالز هور المقطوفة فى أبهى هيئة لأطول فترة ممكنة.

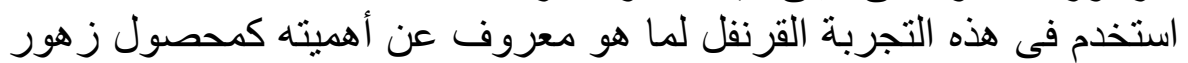

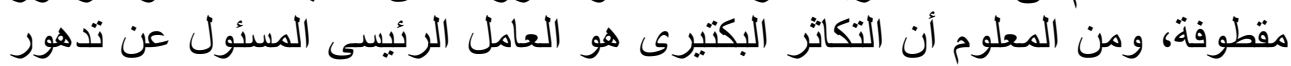

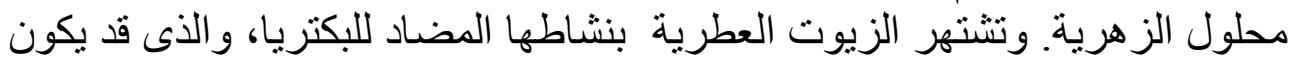
مجدياً فى تحسين مو اصفات محلول وتُ الزئه هرية.

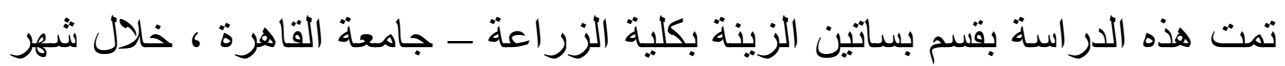

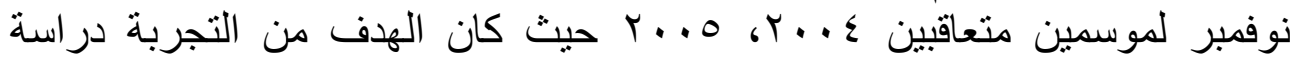

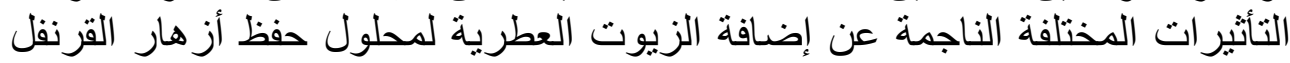

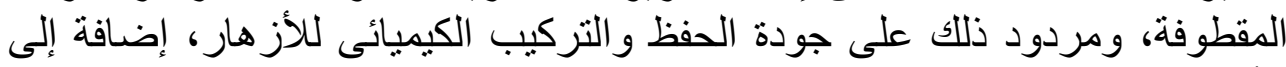
الأمان البئُى و الجو انب الإقتصنادية.

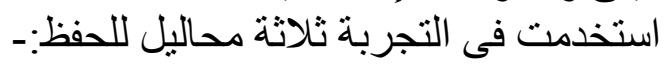

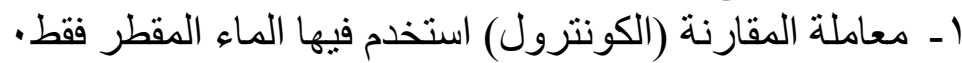

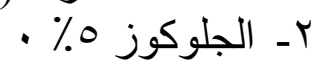

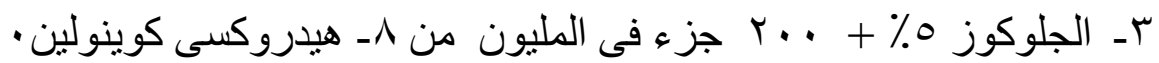




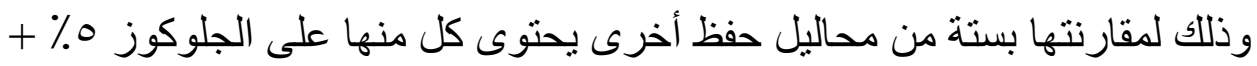

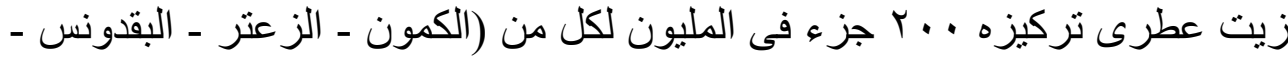

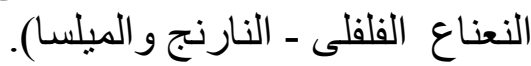

تركت الزهور في محلول الحفظ حتى نهاية حياتها. وقد شملت النتائج المسجلة

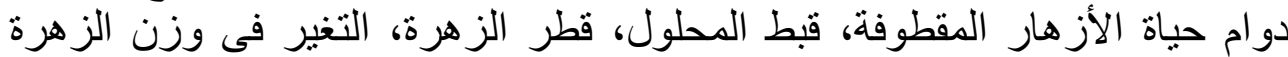

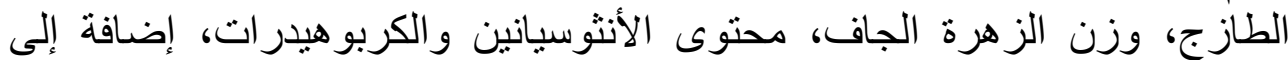

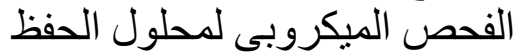

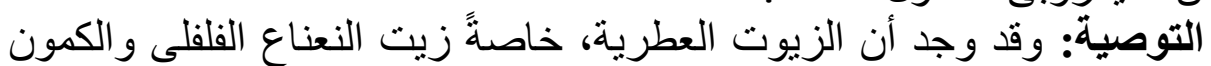

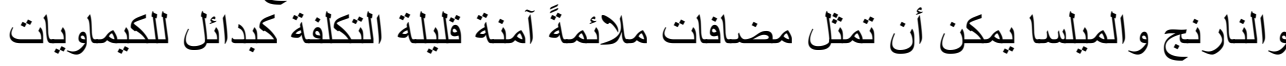

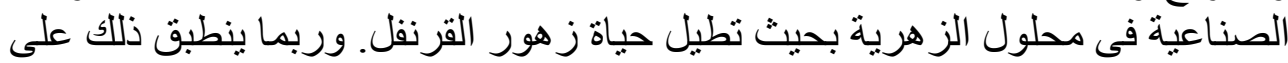

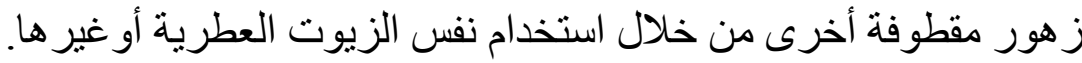

